\title{
Transnational Governance as Contested Institution-Building: China, Merchants, and Contract Rules in the Cotton Trade
}

Amy A. Quark

William \& Mary, aaquark@wm.edu

\section{Recommended Citation}

Quark, A. A. (2011). Transnational governance as contested institution-building: China, merchants, and contract rules in the cotton trade. Politics \& Society, 39(1), 3-39. 
Transnational Governance as Contested InstitutionBuilding: China, Merchants, and Contract Rules in the Cotton Trade
Politics \& Society

39(I) 3-39

(C) 20I I SAGE Publications Reprints and permission: http://www. sagepub.com/journalsPermissions.nav DOI: I0.I I77/00323292I 0394997 http://pas.sagepub.com

@SAGE

\author{
Amy A. Quark'
}

\begin{abstract}
We are in an era of uncertainty over whose rules will govern global economic integration. With the growing market share of Chinese firms and the power of the Chinese state it is unclear if Western firms will continue to dominate transnational governance. Exploring these dynamics through a study of contract rules in the global cotton trade, this article conceptualizes commodity chain governance as a contested process of institution-building. To this end, the global commodity chain/global value chain (GCC/GVC) framework must be revised to better account for the broader institutional context of commodity chain governance, institutional variation across space, and strategic action in the construction of legitimate governance arrangements. I provide a more dynamic model of GCC governance that stresses how strategic action, existing institutions, and dominant discourses intersect as firms and states compete for institutional power within a commodity chain. This advances our understandings of how commodity chain governance emerges and changes over time.
\end{abstract}

\title{
Keywords
}

transnational governance, commodity chain, legitimacy, institutional change, contract arbitration

'College of William \& Mary, Williamsburg, VA, USA

Corresponding Author:

Amy A. Quark, Department of Sociology, The College of William \& Mary, Morton Hall Room 209,

Williamsburg, VA 23I85, USA

Email: aaquark@wm.edu 


\section{Introduction}

We are in an era of uncertainty over whose rules will govern global economic integration. Disputes between the United States and increasingly powerful states like China and India led to a collapse of the Doha Round of negotiations at the World Trade Organization (WTO). In the controversial case of censorship and cyber attacks between China and the global corporate giant Google, a representative from the Chinese Foreign Ministry warned that Google must adhere to China's laws and regulations if it wants to access the growing Chinese market. ${ }^{1}$ And in negotiations over contract rules for the global cotton sector, global commodity merchants such as Cargill and Louis Dreyfus have found themselves in a face-off with the Chinese state over how contract rules should be standardized globally. These struggles raise critical questions about how transnational governance institutions are constructed as legitimate and enforceable on the global stage.

Despite the prominence of such struggles, a key school of thought on transnational governance, the global commodity/value chain $(\mathrm{GCC} / \mathrm{GVC})$ approach, largely overlooks these dynamics. GCC/GVC scholars focus on typifying governance structures and forms of coordination in diverse commodity chains and understanding their implications for weaker actors' ability to "upgrade" into more profitable activities. As such, GCC/GVC scholars give little attention to how transnational governance institutions are constructed to begin with-that is, to the contested processes of institution-building.

I explore the idea of commodity chain governance as a contested process of institution-building through a study of negotiations over contract rules in the global cotton trade. These negotiations offer an interesting case as current dynamics in the sector reflect broader geoeconomic and geopolitical tensions. Transnational cotton merchants gained significant economic power in the cotton trade from the 1970s to the 1990s. However, with the phase-out of the Multi-Fibre Arrangement (MFA) from 1995 to 2005 and the accession of China to the WTO in 2001, China burst onto the scene as a major player in cotton imports. The case of cotton contract rules thus highlights the roles of both private corporations and geopolitical/geoeconomic competition in unfolding negotiations over contract rules.

Evidence from this case suggests that understanding processes of institution-building within commodity chains requires addressing key weaknesses in the GCC/GVC framework. As a range of scholars have noted, GCC/GVC scholars have largely ignored how the broader institutional context in which commodity chains are embedded influences governance. In this way, they overlook how actors' interests and relative power are constituted in part by existing institutions. Furthermore, GCC/GVC research overlooks institutional variation across space. As such, GCC/GVC scholars largely see governance structures as directly structuring the distribution of profits along a chain through the functional division of labor, missing the more subtle competitive advantages gained by convincing others to "play by your rules." Finally, agency is underspecified in the GCC/GVC framework. While the GCC approach is based on a view of 
transnational corporations that "organize" the chain and supplier firms that try to "upgrade," agency in the construction of specific forms of coordination like contracts is overlooked.

I address these oversights in order to specify a more dynamic model of commodity chain governance that gives attention to how actors strategize and struggle in a competition to inscribe their institutional preferences in new governance forms. In this view, actors, and particularly more powerful actors, should be viewed as institutional entrepreneurs who cannot automatically govern a commodity chain but rather strategically construct new governance institutions that reflect their interests and will be accepted as legitimate by other actors. At the same time, actors' interests, strategies, and bargaining power are constituted through their differential embeddedness in existing institutional contexts across space, at various scales, and particularly in dominant, already-global institutions.

Through this analysis, I make three central arguments. First, I argue that the negotiation of cotton contract rules was a contest over whose rules would become global rules. In the cotton trade, different actors have historically been embedded in distinct institutional arrangements governing contracts, including formal versus informal rules, private versus state-led rules, and rules governing national, regional, or postcolonial trade, each with distinct business practices, customs and understandings of what is fair and just. Given this differential embeddedness and the advantages that come from playing by your own rules, we see that the most powerful actors - transnational merchants and the Chinese state-struggled over whose trade association would govern global contract rules, while weaker actors struggled against the imposition of transnational merchants' preferred rules.

My second argument is that broader institutional shifts on a global scale play a critical role in shaping the power dynamics in sector-specific institution-building. In negotiations over cotton contract rules, the relative bargaining power of transnational merchants versus the Chinese state and Chinese textile manufacturers was constituted through broader institutional shifts exogenous to the cotton trade itself: the end of the Multi-Fiber Arrangement; the accession of China to the WTO; and the 1958 New York Convention on the enforcement of foreign arbitral awards. The former two shifts constructed China as the new powerhouse in cotton imports, giving the Chinese state and Chinese textile manufacturers significant power to challenge the conventional trader-driven governance structure of the cotton trade. The latter shift, however, gave transnational merchants a privileged position in governance negotiations as their preferred, privatized form of contract governance and discourses regarding what makes contract governance fair were already institutionalized globally through this inter-state agreement.

Finally, I argue that strategic action within these institutional constraints was critical to transnational merchants' efforts to establish global contract rules that would both institutionalize their preferences and be accepted as legitimate by other actors. Transnational merchants acted as institutional entrepreneurs who retooled their existing institutions, gave strategic concessions, and drew on legitimating discourses to patch together an institutional arrangement that other actors would accept. Given 
their differential institutional embeddedness, paired with their shifting competitiveness in global markets, weaker actors responded differently to merchants' proposed governance solutions.

Through this study, I attempt to hold together a range of concerns that have been raised regarding the GCC/GVC literature. First, I am responding to Bair's call to re-embed GCC/GVC governance in its broader institutional context. ${ }^{2}$ At the same time, I am building upon the Manchester school in economic geography in its attempt to bring questions of institutional variation into $\mathrm{GCC} / \mathrm{GVC}$ research. ${ }^{3}$ Third, by focusing on institution-building, I respond to Gibbon and Ponte's call for a better understanding of how certain forms of governance emerge in commodity chains. ${ }^{4}$ Finally, I try to take seriously the call to adopt a cultural political economic approach to GCC research by giving attention to the critical role of discourse in private governance. ${ }^{5}$

\section{Governance as a Contested Process of Institution-Building}

In recent years, a host of "chain" approaches have been widely used to study new forms of transnational governance. While emerging from various traditions, most prominent in sociological and interdisciplinary research are the global commodity chain (GCC) and global value chain (GVC) approaches. Hopkins and Wallerstein first introduced the GCC approach as a critique of the methodological nationalism that dominated theories of development and economic change. ${ }^{6}$ Rather than analyzing trade among nation-states, it allowed researchers to conceptualize how production and distribution processes stretched across national borders.

The research agenda of Gary Gereffi and his associates has been at the center of the GCC literature. In the mid-1990s, these scholars emphasized the emergence of private governance forms on the global stage. They examined how "lead firms" come to "drive" an entire sector by controlling nodes of the commodity chain with high barriers to entry $^{7}$ or, in a later formulation, through the ability to determine the functional division of labor on the chain (who does what, using what standards, to which specifications and at what price). ${ }^{8}$ From this type of analysis, Gereffi distinguished between two major types of governance structures - producer-driven and buyer-driven.

The producer-driven/buyer-driven distinction aimed to capture the overall power structure of a commodity chain. It could not, however, explain how the relationships between specific nodes in the chain were coordinated. ${ }^{9}$ In his later work under the auspices of the global value chain (GVC) approach, Gereffi and his associates shifted focus to this latter dimension - to delineate different "forms of coordination" within commodity chains, or the specific mechanisms through which firms manage "handsoff" control of supply chains. ${ }^{10}$ They argue that the coordination of interfirm transactions is largely determined by asset specificity, or the complexity of transactional information and the relative importance of codification in facilitating hands-off control. ${ }^{11}$

By exploring the distinct organizational logics of different commodity chains, the GCC/GVC research tradition makes important contributions to our understanding of 
how new forms of private governance redistribute the benefits of production and distribution, as well as what opportunities and constraints supplier firms face as they try to "upgrade" into more profitable nodes of the chain. However, in doing so, GCC/GVC scholars have largely focused on typifying governance structures and forms of coordination and exploring their effects. They have given little attention to the processes of institution-building through which governance structures and forms of coordination are constructed and change over time.

Thinking about processes of institution-building rather than just the types and effects of transnational governance is critical for three reasons. First, as Cashore, Auld, and Newsom suggest in their study of environmental certification in the forestry industry, "any comparison of existing standards at one point in time misses the fact that rule development is not static." 12 This is not to say that such comparisons are not useful but that we also need "to understand the processes through which change occurs."13 Second, exploring institution building raises the question of legitimacy in private governance. As economic sociologists have long noted, institutions of economic governance, whether private or state-centered, must be enforceable to be effective and require a degree of legitimacy, or acceptance by other actors, to be enforceable. ${ }^{14}$ This requires the ability not only to develop new governance forms but to persuade other actors to accept and obey them. GCC/GVC scholarship has given little attention to the legitimacy of private governance structures and forms of coordination.

Finally, understanding the dynamic process through which legitimate private governance forms are constructed becomes even more important given current geopolitical and geoeconomic shifts. With the decline of U.S. power since 1970, the current period is an unsettled era characterized by "uncertainty and unpredictability" in which increasingly powerful firms and states challenge previously dominant ones in a struggle over who will inscribe their interests into new institutions that allow expanded accumulation. ${ }^{15}$ These competitive dynamics have the potential to upset the prevailing governance structures that GCC/GVC scholars have documented. For example, GCC scholars point to Walmart as the quintessential example of Western retailers' ability to consolidate economic and institutional power by "occupying points of leverage" in the commodity chain. ${ }^{16}$ However, Appelbaum argues that in China "giant transnational contractors" are emerging who may be able to challenge "the current seemingly unstoppable dominance of giant U.S.- and EU-based retailers as market makers. ${ }^{, 17} \mathrm{He}$ foresees two possible future trajectories: these giant Chinese contractors could use their position as "big suppliers" to challenge Western retailers, turning on its head the idea of a buyer-driven chain; alternatively, they could "upgrade" and become powerful buyers and retailers themselves. Amid this "cacophony of possible trajectories of global change," it is critical to understand the processes through which actors compete to construct governance structures and forms of coordination. ${ }^{18}$

In order to understand processes of institution-building, we must first address three additional critiques of GCC/GVC research. First, and perhaps most widely recognized, is the failure of the $\mathrm{GCC} / \mathrm{GVC}$ framework to consider the broader institutional context in which commodity chain governance is embedded. ${ }^{19}$ While this was a weakness of Gereffi's original GCC framework, this problem has only intensified in the GVC approach. ${ }^{20} \mathrm{In}$ 
their exploration of "forms of coordination," Gereffi et al. explicitly exclude broader institutional contexts from their analysis in order to focus on variables endogenous to the commodity chain: "we feel confident that the variables internal to our model influence the shape and governance of global value chains in important ways, regardless of the institutional context within which they are situated." ${ }^{21}$ Yet, a range of scholars has demonstrated that existing local, national, and supranational institutional contexts can shape private governance. ${ }^{22}$ For our purposes, rather than assuming its irrelevance, we need to assume that the broader institutional context is constitutive of the power dynamics within a commodity chain, including which nodes become critical "leverage points" from which actors can exert influence over the entire chain. In this view, the broader institutional context establishes the terrain of struggle for commodity chainspecific forms of coordination and governance structures.

A second and related critique has been raised by economic geographers through the global production network (GPN) approach: GCC/GVC research does not address institutional variation across space. These scholars note that GCC/GVC scholars do not engage the vast literature on "varieties of capitalism" that demonstrates the existence and persistence of distinct institutional forms, including legitimating discourses, that stabilize capitalism. ${ }^{23}$ We need to consider that firms may have distinct interests in and pursue different strategies for economic governance given their specific histories, their cultural practices and worldviews, and the institutional contexts in which they are embedded. ${ }^{24}$ Forms of coordination are never merely neutral, efficient rules. Rather, forms of coordination always represent someone's institutional preference or a compromise negotiated amid competing institutional preferences and conflicting understandings of what is fair and just. At the same time, forms of coordination do not only specify the distribution of profits in a commodity chain. They also structure competitive advantages in more subtle ways by determining who can play by the rules, business practices, and cultural understandings with which they are most familiar. Understanding how institutional variations converge in the construction of global institutions thus means replacing the GCC/GVC's focus on economic structure with a spatialized, cultural political economic approach. We must understand how any form of coordination such as a standard or contract is constructed through material and discursive contestation over whose institutional preferences will prevail.

Finally, the nature of agency in processes of global institution-building is underspecified in the GCC/GVC framework. Gereffi's original GCC formulation does stress the agency of transnational firms in the construction of private governance structures, as transnational firms organize the functional division of labor in a chain in ways that allow them to capture the most profits while disciplining suppliers from a distance. Other scholars also note the agency of weaker actors, such as suppliers, who attempt to change their position in this division of labor by "upgrading." 25 In the later GVC approach, however, power and agency fall out of focus. Forms of coordination emerge from asset specificity, not through political struggles and strategies ${ }^{26}$ Even in the more 
agency-sensitive GCC version, however, there is little explanation of the processes through which legitimate institutions are built.

I suggest that we can revise the GCC/GVC framework to capture processes of institution-building by addressing these three weaknesses. This means understanding, as Block suggests, that "there are many varieties of capitalism and there are many different ways that these varieties can be articulated together into a global system." ${ }^{27}$ As such, forms of coordination and the broader governance structure of a commodity chain cannot be simply read off the economic structure or the asset specificity of the chain. Rather, they should be understood as constructed through competition and strategic action that is embedded within existing institutional arrangements across space and at various scales.

To this end, we must see transnational firms not simply as "lead" firms by virtue of their control of the most profitable nodes of a chain, which has somewhat static connotations. While their functional position on the chain is of critical importance, a more dynamic view would also conceptualize them as "institutional entrepreneurs." 28 As institutional entrepreneurs, transnational firms - and other actors along the commodity chain - work to develop institutional solutions and to mobilize other actors to support particular institutional arrangements. ${ }^{29}$ Strategic action is critical as they must "creatively recombine and extend the institutional principles at their disposal to devise new institutional solutions to their problems." ${ }^{30}$ It is through such strategic action that actors respond to challenges to their dominance and compete to translate their economic power into institutional power.

Institutional entrepreneurs operate within existing institutional arrangements, which shape strategic action vis-à-vis transnational governance. In this view, national or supranational institutional arrangements are not external to commodity chain governance but rather are constitutive of actors' interests and strategies in governance negotiations. Actors in commodity chains - including transnational firms - are not "placeless" entities that merely choose the most efficient solutions to their institutional problems. Rather, they are embedded in a wide array of existing institutional structures, such as state institutions, private associations, informal customs, cultural styles of doing business, and legitimating discourses. Actors struggle to have their institutional preferences inscribed into transnational governance arrangements. To achieve this, they reflexively retool institutional technologies and reconstruct discourses to legitimate their institutional preferences as appropriate, efficient, and even fair. At the same time, other actors evaluate new governance arrangements and accept or reject them based on their own embeddedness in existing institutions. In this view, which firms will successfully institutionalize their interests into new private governance arrangements is a critical axis of struggle.

Actors, of course, are not equal in these interactions. Understanding power inequalities in commodity chain governance is a central contribution of the GCC literature. However, GCC scholars tend to put economic power at the center of their analyses. As 
such, they underemphasize the ways in which actors' power is embedded in and constructed through dominant institutions. Institutional shifts exogenous to the commodity chain itself can significantly reconfigure power relations within the chain. For example, the shift to "free trade" governance in the apparel sector through the end of the MFA and the accession of China to the WTO radically reconstituted the power dynamics in the cotton trade, making China the new power player.

Also critical for transnational governance negotiations are the power relations inscribed in what Santos would call already "globalized localisms." 31 The institutional preferences of some actors - particularly Western, transnational firms - have already been institutionalized at the global scale within international organizations and interstate agreements. These actors thus have an advantage in their efforts to further inscribe these preferences into commodity chain governance. For example, we will see that, while cotton merchants had to persuade other actors to accept their contract rules as legitimate, they enjoyed privileges in this struggle as their preferred, private form of contract governance and their discourses about what makes contract governance "fair" had already been institutionalized on the global scale.

In short, we must more carefully trace how strategic action, existing institutions, and dominant discourses all intersect on a terrain of uneven power relations in the construction of private governance. This perspective provides a more dynamic view of governance by focusing on how actors construct legitimate institutions in ways that will serve their interests, but in the context of institutional constraints, many of which are exogenous to the commodity chain itself. This is not to deny that constraints such as asset specificity are important. Rather, it suggests that such variables endogenous to commodity chains are not sufficient to explain the forms of coordination that govern interfirm transactions, how they emerge, and how they change over time.

\section{Method}

I collected and analyzed three types of data using the GCC approach to identify key interviewees and research sites. First, I conducted document analysis of news articles, annual reports, minutes from meetings, and policy documents. Second, I analyzed statistics on changes in global cotton production, consumption, and trade from 1970 to present from a dataset I obtained from the International Cotton Advisory Committee (ICAC). Finally, I utilized a multisited ethnographic research strategy. This involved conducting approximately eighty semi-structured interviews with cotton merchants, textile manufacturers, state representatives, and trade association representatives. I conducted these interviews during field visits to China, Benin, Brazil, Britain, and the United States, as well as during four international cotton industry meetings that I attended: the 2005 and 2006 annual meetings of the ICAC and the 2005 and 2006 annual meetings of the International Cotton Association (ICA). These conferences brought together state and private sector representatives from cotton producing and consuming countries around the world. 


\section{Contract Rules and the Structure of the Cotton Trade}

Contract rules are an economic governance form that enables "actors in markets to organize themselves, to compete and cooperate, and to exchange. ${ }^{, 32}$ Standardized contract rules reduce the transaction costs of trade by providing mutual expectations for buyers and sellers. Standard contract rules govern almost the entire market for bulk commodities, as well as for the air and sea transport, construction, and finance sectors. ${ }^{33}$

A contract in the cotton trade is an agreement between two or more actors to buy and sell a particular quantity and quality of cotton. Individual contracts can be made in isolation from any formal set of rules (although customs and common practices always inform contracts). In general, however, contracts for trading cotton are negotiated in relation to contract rules, or a formalized set of norms outlining common terms of exchange and procedures for settling disputes. Contract rules define the roles and responsibilities that actors assume when carrying out a transaction, such as who will be responsible for storage, transportation, and insurance; how payment will be made; what quality of cotton is being bought/sold and who will verify its quality; and who will settle disputes, the process through which they will be settled, and how they will be enforced.

To understand negotiations over contract rules as a contested process, it is useful to first understand how the cotton trade is organized and the key players involved. Figure 1 provides a snapshot of how the cotton trade is currently organized and embedded within the broader apparel/textile commodity chain. The apparel commodity chain is held up as a key example of Gereffi's buyer-driven commodity chain. However, if we follow the chain to its roots in raw material provision, which is rarely done, we discover a range of other actors - such as merchants and cotton producers - that are typically excluded from the discussion. Gibbon has called the raw material portion a "traderdriven" chain. ${ }^{34}$ The lead firms in this case are transnational merchants who gain dominance in three ways: by globally sourcing commodities to supply other firms, by their command of huge volumes of information from all producing and consuming regions, and by their access to capital and expertise in commodity futures markets. ${ }^{35}$ However, just as Gereffi fails to consider raw material provision in the apparel commodity chain, Gibbon does not account for how raw material supply chains funnel into other commodity chains for finished goods.

Talbot suggests that, to overcome this issue, we might best understand most chains as divided into a few segments, each having their own governance structures. ${ }^{36}$ From this view, we can conceptualize the cotton trade as being "driven" by transnational merchants while, at the same time, it funnels into the buyer-driven apparel segment. Important here is the fact that these different segments can overlap and conflict. ${ }^{37} \mathrm{Gov}$ ernance shifts in the apparel segment, for example, can have significant implications for negotiations over forms of coordination - and the broader governance structureof the cotton segment, as we will see in the implications of the end of the MFA. Indeed, 


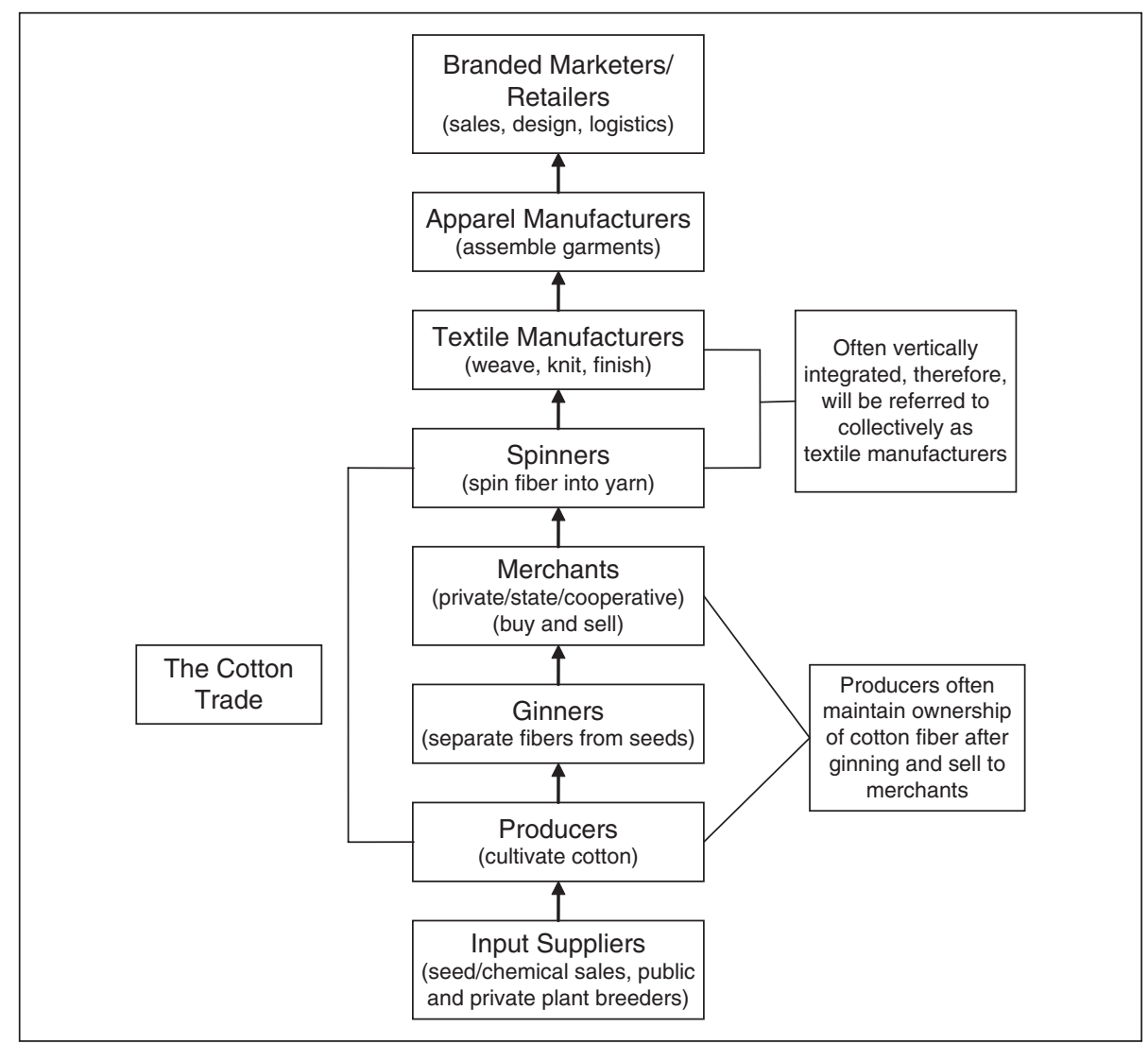

Figure I. The cotton trade within the apparel/textile commodity chain

the way in which the governance structures of different segments of chains overlap is a key source of dynamism in commodity chain governance.

Cotton is grown in more than eighty countries; however, a much smaller number play a significant role in the transnational trade. In fact, the largest exporting countriesthe United States, India, Uzbekistan, the CFA zone bloc of producing countries, ${ }^{38}$ Australia, and Brazil — account for approximately 75 percent of all exports. ${ }^{39}$ Spinning mills in more than one hundred countries consume cotton, but again a smaller number of countries are major players in imports, and, recently, China has come to dominate. In the 2007/2008 season, China accounted for approximately 36 percent of all cotton imports (see Figure 2). The next largest importers that year accounted for much smaller import shares: Turkey (9.7 percent), Pakistan (7.6 percent), Bangladesh (5.9 percent), and Indonesia (5.3 percent). ${ }^{40}$ 


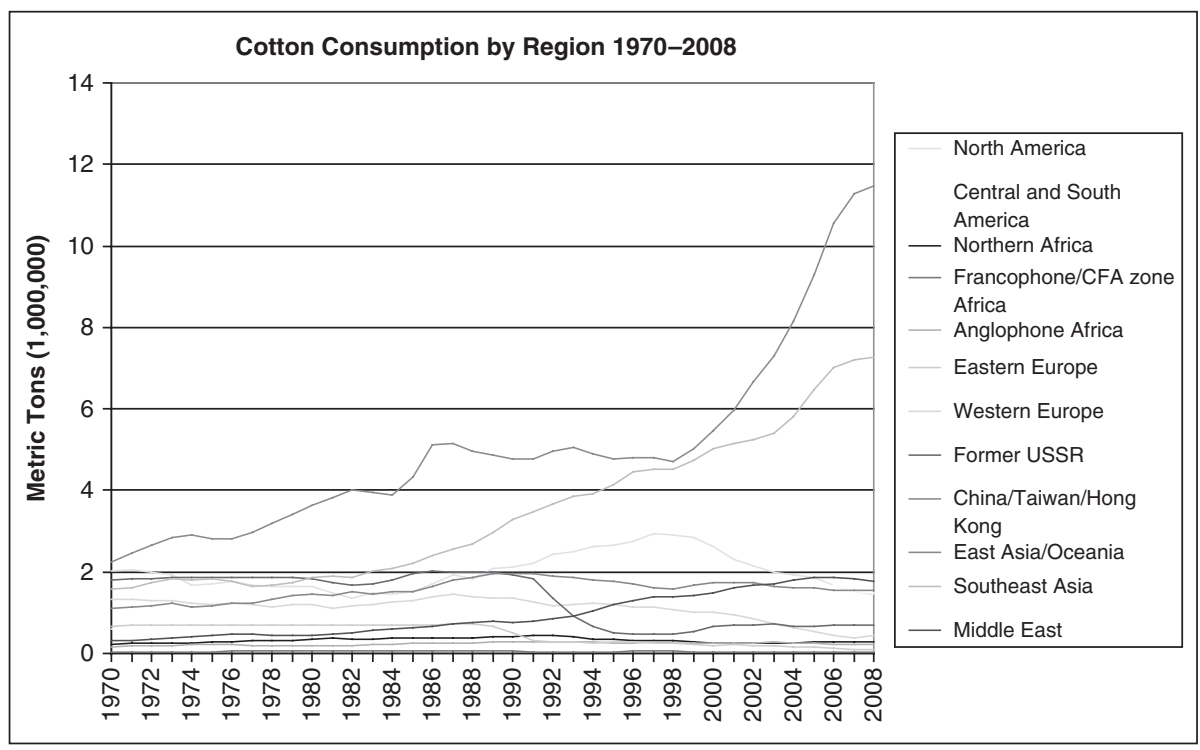

Figure 2.

International Cotton Advisory Committee, Documents of the ICAC (CD-ROM).

Linking cotton-producing countries with cotton-consuming countries are the merchants who have come to "drive" the chain in recent decades. There are thousands of local merchants and hundreds of regional merchants. These smaller firms generally sell cotton purchased locally to transnational merchants who will organize a transnational sale. A small number of merchants conduct the transnational trade. While precise data on market share are difficult to obtain, by the early 2000 s, about ten companies handled more than two-thirds of the transnational trade in cotton. ${ }^{41}$ Industry players, however, suggest that actual consolidation is likely higher; the largest three firms may handle as much as $45 \%$ of the transnational trade.

It is these actors that are involved in negotiations over contract rules. However, they come to negotiations from varied institutional backgrounds. Private companies handle most transnational trade. Private firms generally belong to trade associations in which contract rules are negotiated. In Western countries, private firms and trade associations have a long history of negotiating contract rules, as we will see in the next section. In many countries in the global South, in contrast, state-owned enterprises (SOEs) controlled imports and exports of cotton in the postwar period, including in China, India, Pakistan, Egypt, and the cotton-producing countries of the CFA zone. These SOEs negotiated contract terms for, and settled disputes over, cotton exports or imports on behalf of cotton producers or textile manufacturers. While some have been accused of corruption, SOEs provided a counterweight in negotiations with transnational 
Table I. Cotton Trade Associations 2009*

\begin{tabular}{ll}
\hline Name & Country \\
\hline Alexandria Cotton Exporters Association & Egypt \\
American Cotton Shippers Association (1924) & United States \\
Association Cotonnière Africaine (2002) & Regional \\
Association Cotonnière de Belgique & Belgium \\
Association Française Cotonnière (1895—estimate) & France \\
Associazione Cotoniera Italiana (1883) & Italy \\
Australian Cotton Shippers Association & Australia \\
Bolsa de Mercadorias \& Futuros (1917) & Brazil \\
Bremer Baumwollbörse (I872) & Germany \\
Centro Algodonero Nacional (1887) & Spain \\
China Cotton Association & China \\
Cotton Association of India (1922) & India \\
Gdynia Cotton Association (1938) & Poland \\
Izmir Mercantile Exchange & Turkey \\
Japan Cotton Traders Association & Japan \\
The Karachi Cotton Association (1933) & Pakistan \\
The Liverpool Cotton Association (I882) & UK \\
\hline
\end{tabular}

*These associations are members of the Committee for International Cooperation between Cotton Associations (ClCCA).

Source: Committee for International Cooperation between Cotton Associations, "CICCA," http://www .cicca.info/ (accessed April 2, 2009).

merchants, giving cotton producers and textile manufacturers bargaining power that they could not exercise alone. Some of these SOEs continue to operate, while others have been privatized through structural adjustment programs and neoliberal reforms. ${ }^{42}$ In the wake of SOE privatization, private actors in a number of countries have created private trade associations to negotiate new, nationally focused contract rules (see Table 1). It is from this mixed landscape of public and (in some cases, newly) private rules, focused on national or postcolonial trade networks and rooted in national legal systems, that actors are now negotiating global contract rules.

\section{The History of Anglo-American Contract Rules}

While it could be analytically useful to explore the history of contract rules in any country involved in the cotton trade, it is worth giving attention to the Anglo-American tradition, given its institutionalization in the global arena and thus its particular importance for negotiations around global contract rules. Since the late nineteenth and early twentieth centuries in the United States and Britain, contract rules have represented a relatively privatized governance form, rooted in the notions of freedom of contract and contract sanctity. ${ }^{43}$ Through freedom of contract, states give private enterprises the right to 
enter into binding contracts and to define their contractual relationships individually or through standard sectoral rules governed by private trade associations. Moreover, firms are allowed to settle their own disputes through private arbitral bodies operating independently of state courts. Through contract sanctity, states agree to enforce private contracts and the decisions of private arbitral bodies, as long as they follow the limits and procedures of national laws. ${ }^{44}$ This governance form maximizes the autonomous authority of firms, strengthens the enforceability of private authority, and minimizes the scope for state intervention.

In the postwar period, Western states and firms, led by the United States, attempted to extend this form of contract governance onto the global stage to better facilitate transnational trade. Trade associations in Western countries had developed contract rules that were largely domestically focused, based on national legal systems, which meant their jurisdiction was limited to the jurisdiction of national state courts. At the same time, struggles for decolonization were creating newly independent nation-statesand trade with former colonies based on consent rather than sheer coercion-but there were no legitimate rules to govern this trade. In this context, Western states negotiated the 1958 United Nations Convention on the Recognition and Enforcement of Foreign Arbitral Awards, also known as the 1958 New York Convention. Based on this Convention, firms can contractually bind themselves to settle disputes in a particular state court or through a particular private arbitral body. ${ }^{45}$ By ratifying the Convention, states agreed to enforce the decisions of both other state courts and private arbitral bodies without subjecting them to domestic rules and procedures, unless they contradicted public policy, which was vaguely defined.

Through the 1958 New York Convention, the Anglo-American tradition of contract governance became a "globalized localism" that constructed the power of private firms to negotiate contract rules and settle their own disputes on a global stage. Importantly, the 1958 New York Convention also institutionalized and globalized a particular discourse about what made contract rules "fair" that had emerged in relation to economic liberalism in the nineteenth century. This is the notion that contractual obligations are consensual and derive from the voluntary agreement of the parties to a contract. ${ }^{46}$ From this view, contracts are to be viewed as expressing the wills and desires of individuals,

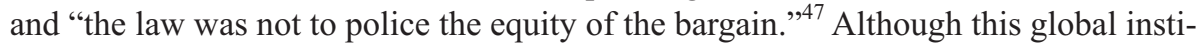
tutional infrastructure was put in place in the immediate postwar period, many sectorsthe cotton trade included — did not begin the process of transnational standardization until much later. ${ }^{48}$

\section{Transnational Merchants, China, and the Rivalry for Institutional Power in the Cotton Trade}

Transnational cotton merchants consolidated economic power within the cotton trade from the 1970s to the 1990s. While the cotton trade has always been relatively global, its global reach expanded significantly as textile firms in Asia outcompeted those in Western countries (see Figure 2). To meet this new demand, domestic-oriented cotton 


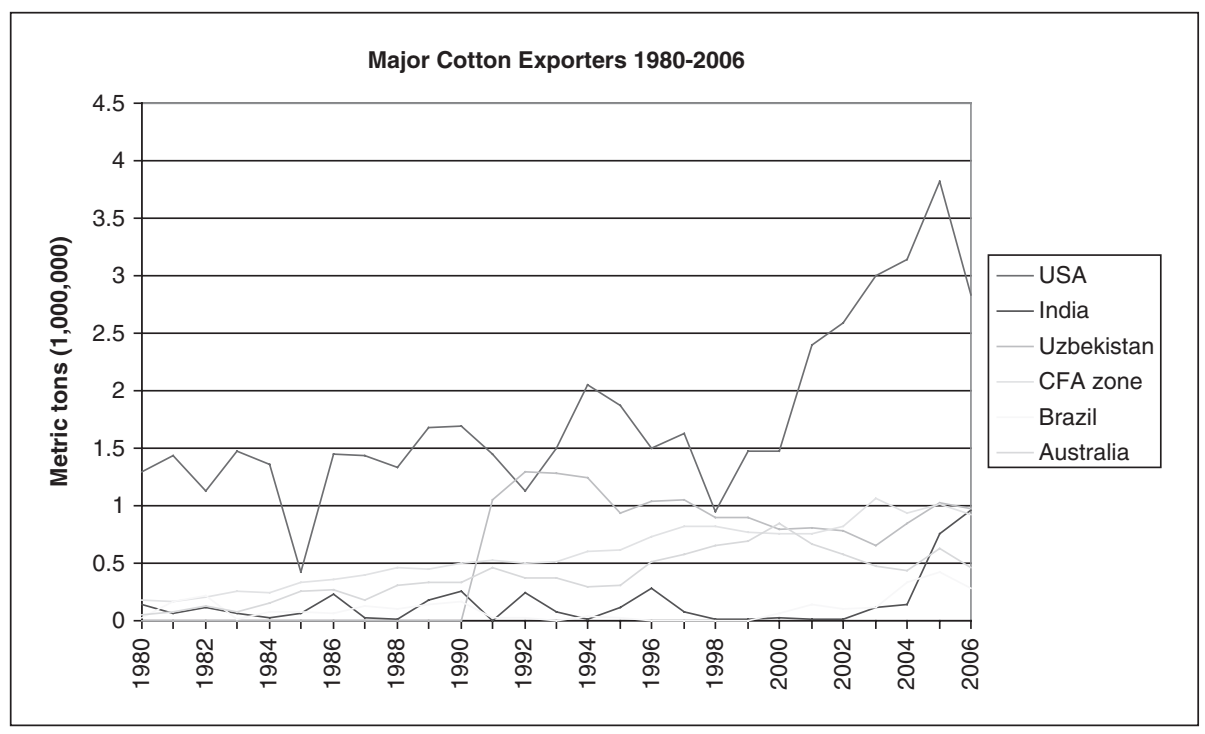

Figure 3.

Ibid.

producers such as those in the United States became exporters, and new cotton exporters emerged in a number of "developing" countries, such as Uzbekistan and countries in CFA zone (see Figure 3). U.S. and European cotton merchants were positioned to capture the most benefits given their position as powerful middlemen between relatively small and geographically dispersed cotton producers and textile mills around the world.

Transnational cotton merchants expanded rapidly despite the lack of globally standardized contract rules to govern their transactions. The lack of standardized contract rules did pose a problem for merchants given the inability of many of their trade partners to manage price risk. Many trade partners in developing countries did not (and do not) have access to or the skills to use price risk-management tools such as futures markets. If actors could not hedge their price risks, they would be much more likely to default on contracts in the case of significant price fluctuations, as evidenced in the "cotton contract crisis" of the $1970 \mathrm{~s} .{ }^{49}$ Despite these problems, efforts to standardize transnational contract rules were overshadowed by new opportunities to gain a competitive advantage in a global market without clearly defined rules. Merchants competed to be reliable suppliers with the ability to absorb price risks and to secure reliable clients who could do the same without defaulting on their contracts. Moreover, as they grew in power vis-à-vis their clients, transnational merchants found themselves in a favorable position to largely impose their contract rules - the rules of the Liverpool Cotton Association (LCA) — on clients. 


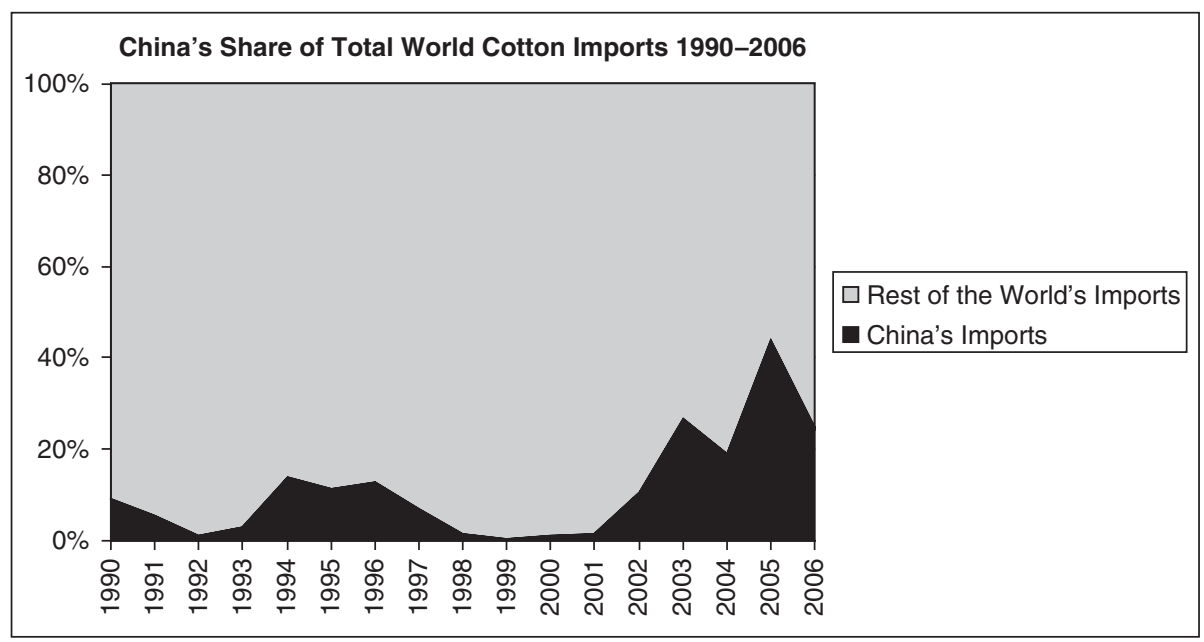

Figure 4.

Ibid.

However, the seemingly unrivalled power of transnational merchants faced a significant challenge with a radical shift in the power structure of the cotton market in the early 2000s. Through negotiations over the Agreement on Textiles and Clothing (ATC) at the WTO, states decided to move from the protectionist quota-system regulation of the apparel sector by the MFA to neoliberal "free trade" governance. As quotas on apparel were phased out, ending completely in 2005 , retailers and branded marketers were able to source apparel from firms in whichever country could offer the lowest prices. With its accession to the WTO in 2001, China was by far the biggest winner as a result of the end of quotas. In the course of a few years, China became the largest producer of textiles and apparel - and thus the largest importer of cotton - in the world. China's share of world cotton imports jumped from 15 percent to 40 percent (see Figure 4).

The radical increase in China's market share reconfigured competitive tensions in the cotton trade and thus the incentives for standardizing rules. The significant market share wielded by Chinese spinning firms after the MFA meant that merchants had more to lose from widespread contract defaults in the Chinese market. When prices fluctuated dramatically in 2004, for example, many Chinese spinning firms defaulted on their contracts as they could not absorb the price loss and remain competitive. This resulted in significant losses for transnational merchants:

We had a really bad experience in China.... We had sold a lot of cotton on pretty good terms - high prices. But then the market dropped and prices fell in halfa 20 to 30 cent drop. And we had a lot of bales in these contracts. And the Chinese mills started defaulting on all these contracts.... This was a huge hit—we're talking millions and millions and millions of dollars. (Top 3 cotton merchant) 
Historically, sanctity of contract did not present a problem in China as contracts were publicly regulated by the country's state-owned enterprise (SOE), the China National Textiles Import and Export Corporation (Chinatex), thus ensuring sanctity of contract. However, China's accession to the WTO in 2001 required a range of neoliberal policy reforms, including the privatization of Chinatex including a requirement to allow private firms to import cotton. Merchants faced an import market comprised of six thousand to ten thousand diverse spinning firms. Some of these spinning firms were large, indeed, the largest in the world, with vertically integrated textile manufacturing operations run by foreign investors or Chinese nationals with broad business experience. Many others, however, were small firms with no experience importing cotton or using transnational contracts, and no experience with or access to price risk-management tools, which were underdeveloped in China at this time.

The problems associated with contract defaults in the Chinese market were intensified given the different legal norms that operated in China. The Chinese state had ratified the 1958 New York Convention; however, as in many developing countries, Chinese state courts did not necessarily enforce private arbitral decisions as per the Convention but rather reopened cases based on the public policy clause. For example, one transnational merchant reported that he took an arbitral award to a Chinese court to have it enforced when the spinning firm refused to pay. The judge decided not to enforce the award to avoid bankrupting the offending spinning firm and leaving hundreds of community members jobless as a result. The Chinese legal system was highly embedded in guanxi, or networks of personal connections. Such situations intensified merchants' interest in creating standardized contract rules that were enforceable in China.

At the same time as merchants' interest in standardization intensified, the Chinese state recognized that contract sanctity was linked to the textile sector's profitability vis-à-vis other countries. Without price risk-management tools, spinning firms needed a good reputation for reliable payment and contract sanctity so that merchants would offer them on-call pricing, or, in other words, extend them credit for a window of time during which they could watch price fluctuations and "call" the best price. If spinning firms could not use on-call pricing, they risked paying more for cotton if prices increased, as a service provider to merchants explained:

About three years ago, there was a price hike of 20 cents per pound. This ended up making Chinese yarns more expensive than Indonesian yarns because Indonesia could use on-call prices and Chinese buyers couldn't as no one trusted them or Chinese arbitration enough to extend them credit. So China was paying 20 cents a pound more for cotton on a spot market while the Indonesian spinners could wait for the price to fall again.

Chinese spinning firms' global competitiveness was reliant on a reputation for contract sanctity. Moreover, the competitiveness of the textile and apparel sectors was critical to Chinese national development overall given the jobs these sectors created.

Far from unrivalled in the construction of private contract rules for the global cotton trade, transnational cotton merchants faced a formidable bargaining foe. The 
Chinese state wanted contract rules that would sharpen the competitiveness of these sectors, and this meant challenging rather than accepting the rules of the transnational merchants' trade association, the LCA. Like many industry players around the world, the Chinese state considered the LCA rules to be trader-biased-developed by, and in the interests of, transnational merchants. One of the LCA's arbitrators explained this perception: "It's because they are trader-biased! But others could come and join our organization and change them." The Chinese state could not, however, continue to govern contract rules directly, given the privatization of Chinatex. Instead, as in other industries, in 2006 the state established a trade association - the China Cotton Association (CCA) - that was related to the state through a "state corporatist relationship." 50 The CCA would develop a standard contract that would serve as an "industry best practices" model for their inexperienced spinning firms.

Given their significant dependence on transnational merchants, the CCA decided that the merchants' trade association, the LCA, could negotiate with them over the standard contract. Merchants preferred to negotiate from the starting point of the LCA rules rather than the CCA rules. Whose rules mattered, as the LCA and the CCA were not merely negotiating over the content of the rules. Contract rules were embedded in trade associations that would oversee these rules in the future and would make decisions regarding how rules should change and be interpreted. From this perspective, the trade association under which negotiations would unfold could have implications for who would have authority over rules in the future. Despite this less than ideal situation for merchants, the LCA agreed to negotiate - any rules were better than no rules, at least in the short term.

Two issues were particularly contentious in negotiations. First, as the 1958 New York Convention allowed transacting parties to settle disputes through private arbitral bodies instead of state courts, a central point of contention was over whose arbitral body would settle contract disputes. The merchants wanted to name the LCA as the arbitral authority, while the CCA wanted disputes arbitrated by the China International Economic and Trade Arbitration Commission (CIETAC). As sociolegal scholars argue, which private arbitral body settles disputes matters, as they can vary significantly based on their historical development in relation to the domestic legal professions, arbitral practices, and legal systems of particular countries and/or sectors. ${ }^{51}$ Different arbitral bodies and arbitrators have different conceptions of what arbitration should look like and how it should operate. Therefore, which arbitral body is used determines who is "able to play by their own terms." 52 The LCA, for example, was steeped in the private rules, norms, and culture of the transnational cotton merchant community, had developed out of the Anglo-American arbitration tradition and legal systems, and was developed to address the technical specificities of the cotton trade. CIETAC, in contrast, was developed in relation to the legal rules and cultural norms in China and conducted arbitration for commercial disputes across a range of sectors. Santos suggests that, by demanding use of its arbitral body in disputes in a number of sectors, the Chinese state and Chinese firms are trying to impose some of the particularistic qualities of Chinese capitalism and Chinese modernization on private arbitration practices. ${ }^{53}$ 
The second highly contentious issue was the quality terms of the contract. Cotton contracts commonly include a quality penalty, which dictates the penalty to be paid per bale if the quality of the shipment is found to be below the quality range stated in the contract. Merchants aim to keep this penalty low as they have historically made money by agreeing to a certain quality range but then shipping in the bottom end of the range or including a few subquality bales. Also, merchants assume the risk that the quality of bales could change during transport due to improper storage or water damage. Spinning firms, on the other hand, desire high-quality penalties, as the quality of their yarn depends on receiving the cotton quality that they purchased, and they generally produce yarn to meet the quality specifications of a particular sales contract. To ensure the interests of the Chinese textile sector, the CCA wanted high-quality penalties ${ }^{54}$ From the perspective of the transnational merchants who trade millions of bales a year, this was an unreasonable demand. As one vice president explains: "There are huge penalty differences [between the CCA contract and the LCA contract]. $\$ 30$ per bale vs. $\$ 3$ dollars per bale!"

After tense negotiations, the CCA and the LCA came to a compromise on arbitration. The CCA agreed to allow parties to choose either CIETAC or LCA arbitration. However, the CCA refused to compromise on quality terms in the official version of the contract. In so doing, the CCA essentially declared a stalemate in efforts to develop standardized contract rules.

\section{The Need for Legitimate Cotton Contract Rules}

The CCA's challenge compelled transnational cotton merchants to pursue new strategies in order to ensure their future economic and institutional power in the cotton sector. Not only were transnational merchants dissatisfied with the official rules that the CCA ultimately released, they were also concerned that these rules favoring textile manufacturers would become the foundation for a broader standardization of contract rules for the global cotton trade. Given this threat, the LCA decided to solidify its leadership in the sector. Specifically, the LCA proposed that private trade associations representing merchants and textile manufacturers around the world should adopt the LCA contract rules as the global rules governing cotton contracts (see Table 1). It cast its proposal as representing the general interest of the "cotton community" as a whole, as the president of the ICA explained:

China is now a Member of the WTO and by the end of the year 2005 is likely to represent close to 40 percent of the world's cotton consumption.... It is time now to work closely with our Chinese friends on the issue of cotton trade rules in China. ... History has shown that wherever there is not a clear understanding of rules, disputes are much more likely to occur. It will be in the interest of the entire world to make sure that this clear understanding is in place. ${ }^{55}$ 
LCA officials urged others in the industry to "take up the call for further growth in trade through standardization.. ${ }^{56}$ They hoped that standardization around their rules in the sector as a whole would give them greater bargaining leverage vis-à-vis the CCA. At this time, the CCA was not a member of the key international cotton organizations, such as the Committee for International Cooperation among Cotton Associations (CICCA), due to Taiwan's participation.

Other cotton trade associations, however, echoed the CCA's critiques that the LCA rules were trader-biased and thus were reluctant to replace their own rules and procedures with those of the LCA. Textile manufacturers in Turkey and Bangladesh, for example, raised concerns about a range of rules which they perceived as protecting merchants more than spinners, including the rules for delay in shipment, quality complaints, and sellers' late payment of claims for weight and quality. ${ }^{57}$ A number of textile manufacturers also considered LCA procedures for arbitrating contract disputes to be biased. The LCA rules, like the rules of the European cotton associations, specified a practice called "invoicing back," which tried to resolve disputes by returning transacting parties to the same situation they would be in if the contract had been fulfilled normally. In both the LCA rules and those of the continental European trade associations, for example, if a merchant did not deliver cotton to a textile manufacturer as specified in a contract, the merchant would have to repay any money that the textile manufacturer had already paid for the shipment, plus the difference between the price stated in the contract and the spot market price at the time of default, which would allow the textile manufacturer to purchase cotton to replace the portion that was not delivered.

The LCA rules on invoicing back, however, diverged from the rules of the European trade associations in key respects. First, the LCA rules did not allow aggrieved parties to claim additional damages related to a contract default. An LCA official explained: "LCA rules don't address consequential costs or losses. Like if the cotton doesn't arrive, what additional costs this creates for spinners." Losses or costs incurred as a result of the contract nonperformance could not be claimed, unless the parties added specific additional contract terms that deemed specific consequential costs recoverable. ${ }^{58}$ Moreover, the LCA had what was considered an adversarial arbitration system, or a "hired gun" system, in which each party to the dispute paid an arbitrator and a two-person panel decided the outcome. The end result was thus significantly influenced by parties who could compensate the best arbitrator; countries in the global South felt this put them at a significant disadvantage because arbitrators could charge between 75 to 150 GBP per hour (approx. $\$ 150$ to $\$ 300$ USD). ${ }^{59}$

Trade associations were also skeptical of the biased authority structure of the LCA. The LCA wanted to claim global authority, yet its executive board, its key decision-making committees, and its membership in general did not represent the diversity of actors in the global cotton trade. The LCA was largely a trade association of Western-based merchants, and the majority of the organization's officers, as well as officially recognized arbitrators, were U.S. and British merchants and specialized arbitration firms. 


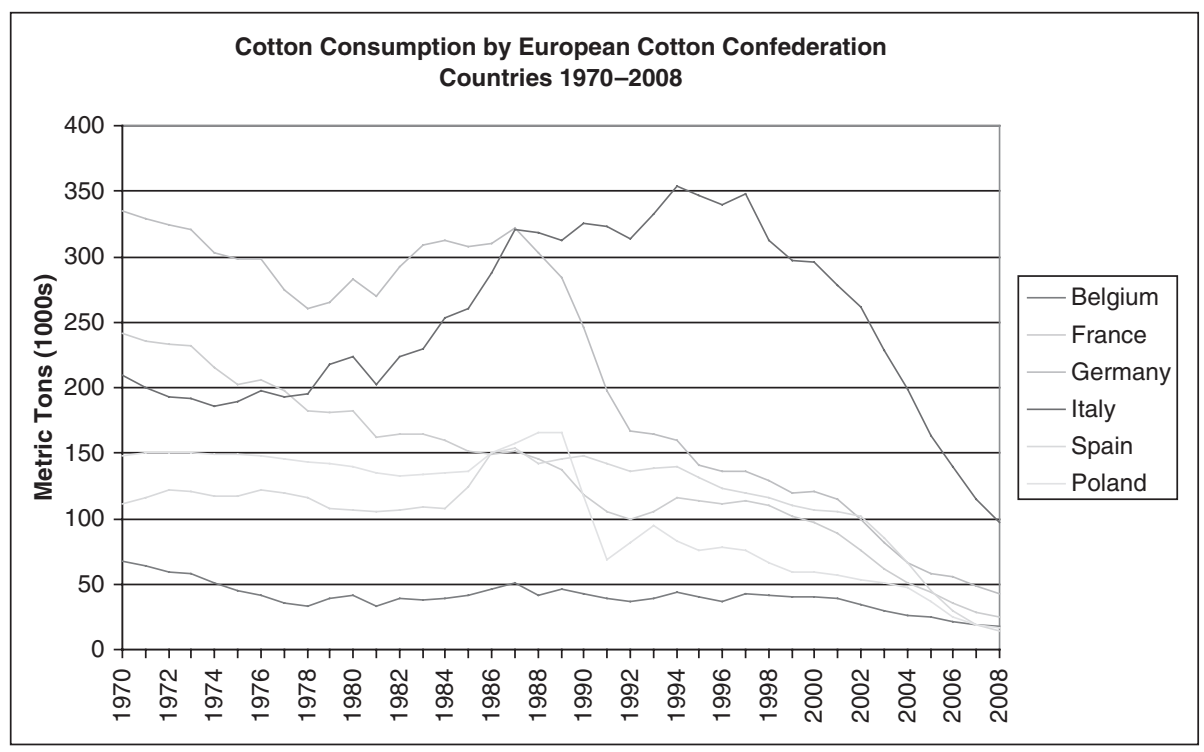

\section{Figure 5.}

Note: Data for Germany includes both East and West Germany prior to unification. Source: International Cotton Advisory Committee, Documents of the ICAC (CD-ROM).

The resistance to the LCA rules was not resistance to global standardization per se. Rather, textile manufacturers and domestic merchants in other trade associations simply had different interests in what global rules should be, given their historical embeddedness in different contract governance institutions. In this context, different trade associations responded differently to the LCA's standardization proposal, depending on their different positions in the sector. The continental European trade associations and cotton exchanges, ${ }^{60}$ for example, had developed their own contract rules and arbitral bodies in the late 1800 s and early 1900 s to govern cotton imports. The European associations were adept at using their own rules and procedures to secure advantages in contracts and arbitration and were not interested in adopting the ICA rules. At the same time, however, the European textile industries had declined precipitously in recent decades (see Figure 5), and their trade associations were attempting to stave off their decline in both market share and influence within the transnational cotton trade (see Figure 6). In 1999, the seven European cotton trade associations, including the LCA, had formed the European Cotton Confederation (ECC) to promote greater cooperation in the European industry. ${ }^{61}$ When the LCA proposed the adoption of its rules, the remaining members of the ECC decided instead to negotiate standard European rules for cotton contracts and arbitration, in part due to the commonalities between the contract rules and arbitration procedures based in the continental European civil law tradition versus the Anglo-American common law tradition. The ECC thus launched a 


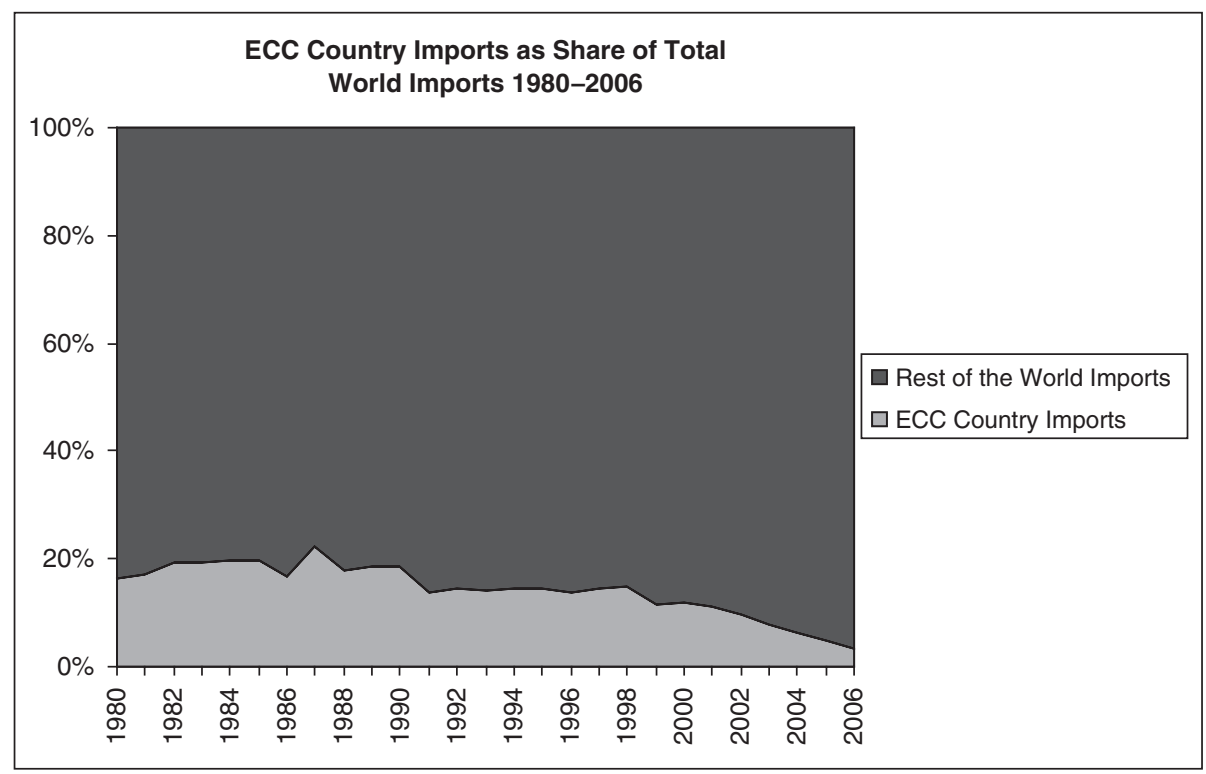

Figure 6.

lbid.

competing effort to construct standardized contract rules, contesting whose association should lead global standardization.

For textile manufacturers and domestic merchants in many other countries, adoption of the LCA rules would reflect a much more profound shift in contract governance. Like in China, many states in developing countries had established state-owned enterprises (SOEs) to import and export cotton in the postwar period, including India, Pakistan, Egypt, and the cotton-producing countries in the CFA zone. From the 1980s to the 2000s, however, the International Monetary Fund (IMF) - and later the WTOpushed for the privatization of SOEs in cotton and other sectors, citing them as inefficient and/or barriers to free trade. In the newly privatized environment, however, textile manufacturers, domestic merchants, and cotton producers in these countries were inexperienced and faced a cadre of powerful transnational merchants who wanted to impose their rules and arbitral procedures. In this context, many actors in developing countries had little choice but to accept LCA rules and arbitration in their contracts. Trade associations in developing countries were thus reluctant to formally adopt the LCA rules.

Some of the most vocal protests came from textile manufacturers and merchants in the Indian cotton industry, who argued that the fact that there were only a few large transnational traders and thousands of small spinners in India put them at a bargaining disadvantage. ${ }^{62}$ This is what also drove Indian firms to contest LCA arbitral decisions in state courts - a practice that transnational merchants were hoping to eliminate. Like 
firms in other developing countries, Indian firms saw state courts as places to turn when more powerful transnational merchants forced them into unfair deals.

Unwilling to adopt what they saw as biased LCA rules and arbitration procedures, Indian buyers and textile manufacturers adopted a different strategy. They developed a standard contract for importing cotton to India. ${ }^{63}$ These were nationally focused rules that Indian firms wanted to use for imports and exports from India to offset what they saw as their significant bargaining disadvantage in the global market. The LCA was not pleased with this development. As an LCA official explained:

A few years back when we started the standardization [of contract rules], India appeared to be a real threat as they didn't want to adopt the LCA rules. They thought the LCA rules represented Western companies and Western power trying to impose on them and dominate them. They didn't want to accept them. They wanted to use Indian law and Indian arbitration.

Ultimately, however, the LCA largely dismissed the Indian associations' protests. At this time, India was still a relatively small player in the transnational trade. While transnational merchants had suffered losses due to contract defaults in the Indian market, they were not about to use the Indian standard contract or negotiate on the Indian industry's terms.

\section{Constructing Legitimacy over Contract Rules, Creating Opportunities for Weaker Actors}

Amid these criticisms of the LCA as a biased institution that did not represent the interests of diverse constituencies in the transnational cotton trade, the LCA realized that if it wanted to use standardization to gain leverage vis-à-vis the CCA, it would need to establish leadership more through consent than coercion. To this end, the LCA decided to launch a campaign to construct hegemony: (1) by changing key rules to gain weaker actors' consent; (2) by discursively framing LCA rules as "ethical" business practices; and (3) by making its authority structure more representative. The LCA hoped that these efforts would persuade other trade associations to join the LCA, ultimately bolstering its bargaining power vis-à-vis the Chinese state. For other trade associations, the LCA's bid for hegemony created new opportunities to have their voices heard. Depending on their competitive positions, different trade associations would choose to adopt or resist the LCA rules in attempts to gain relatively greater institutional power over contract rules into the future.

The LCA's first strategy was to evaluate and revise their rules in order to claim their impartiality. The LCA compared its rules and procedures with those of other private trade associations and arbitral bodies, such as the Sugar Association and the Grain and Feeds Trade Association. Further, it invited the Chartered Institute of Arbitrators to provide an assessment of the strengths and weaknesses of its arbitration procedures in comparison to other UK-based trade associations. Based on these evaluations, one of the key changes made was to its arbitration practices. The LCA 
decided to replace its adversarial arbitration system with a tribunal system, more similar to the one used in the continental European trade associations. In the new tribunal system, each party would still appoint and pay an arbitrator, but the LCA would also appoint a chairperson to each arbitration panel. This chairperson would manage the arbitration and would have the final vote on the arbitral award. In addition, any and all payments for arbitration would have to be made through the ICA Secretariat to ensure transparency. ${ }^{64}$

The LCA was not willing, however, to change its controversial invoicing back rules. Instead, it made a strategic interim concession to other trade associations. The LCA announced that it would allow trade associations to adopt the LCA rules without adopting LCA arbitration. This meant that industry players would write their contracts according to LCA rules but, in the case of a dispute, they would settle it using the procedures of their national trade association. This represented a significant-but strategic - concession. By letting cotton associations keep arbitration within their own associations, transnational merchants put aside for the time being their goal of establishing the LCA as the authoritative arbitral body for the industry. In this way, it would keep continued conflict over LCA arbitration procedures - and the failure to link blame with breach of contract-from halting all standardization efforts. At the same time, it would achieve perhaps a more important goal: constructing broader support for private arbitration and enforcement outside of state courts. When transnational merchants had pushed clients to use LCA arbitration, they had responded by turning to state courts when disputes arose. Allowing members of other trade associations to use their own arbitral bodies meant that transnational merchants would have to loosen their control over arbitration but would increase the acceptance of private arbitration and enforcement. If actors were using their own arbitration bodies and procedures, they would be more likely to respond to private enforcement mechanisms like blacklists and less likely to challenge arbitral decisions in state courts.

The LCA's second strategy was to use these rule changes as the basis of a discursive campaign to claim its impartiality and thus its legitimate leadership in the standardization of global contract rules. To launch this effort, in 2004 the LCA re-branded itself as the ICA, the International Cotton Association. The president of the new ICA declared: "By altering our name we are making a statement to the world. We are the internationally recognized arbitral body for cotton.." ${ }^{, 55}$ The ICA argued that for members of the "cotton community" to benefit from expanding global trade, the cotton trade had to be based on "ethical" trading practices. From the ICA's perspective, those who upheld contract sanctity were ethical businesspeople, while those who defaulted on contracts were not. The ICA argued that adopting its rules, as well as the blacklist as a private enforcement mechanism, was:

... for your own protection. It serves us nothing if our competitors do not obey the rules, and attempt to seek some advantage over the honest guys. The responsibility of enforcement is not the Association's, it is yours, it must be the collective effort of all of us, to ensure that those who do not take our rules seriously, find themselves isolated. ${ }^{66}$ 
This construction of "ethical" business practices, however, was biased toward larger players who had access to and the expertise to use price risk-management tools (such as hedging in futures markets), and thus could manage their risk without resorting to contract defaults.

Through this "you're-with-us-or-against-us" mentality, the ICA argued that the adoption of the ICA rules represented the solution to the lack of common, ethical contract rules for the global cotton trade. The president of the ICA insisted:

The world needs one major trade body and one international set of rules. . . The [ICA's] new rules for arbitration create an open transparency within our system and it will be extremely hard to argue against the impartiality of the [ICA] now that this has been created. . . I I also believe that the new rules . . . will help to address any misconceived perceptions that the [ICA] is not a completely fair and impartial body. ${ }^{67}$

In this way, the ICA aimed to distinguish its own neutrality and impartiality with the unfairness of other potential solutions, such as using nationally focused rules that represented the narrow interests of only some actors. ${ }^{68}$

To promote this message, the ICA launched an educational campaign to familiarize textile manufacturers and merchants, particularly in developing countries, with the newly revised ICA rules. The ICA posted the new rules, a guidebook, and a standard model contract on its website and translated the ICA rules into four languages in addition to English: French, Portuguese, Russian, and Mandarin. ${ }^{69}$ Moreover, from 2006 to 2009, subsequent presidents, the director general, and other ICA members held interactive workshops and presentations in China, Turkey, India, Bangladesh, Uzbekistan, Australia, Ghana, Benin, Burkina Faso, Geneva, Tanzania, Brazil, and the United States. ${ }^{70}$

Finally, the ICA tackled concerns that its authority structure was unrepresentative by diversifying its directorships, its network of arbitrators, and its Rules Committee. In addition to its officers and ordinary directors, the ICA added a new category of associate directors, who would be "especially appointed to represent the interests and concerns of international members of the ICA and the principal overseas cotton producing and consuming regions. ${ }^{, 71}$ By 2007, the ICA had appointed associate directors to represent the African Cotton Association, the Indonesian Textile Industry, the Pakistan Cotton Textile Industry, the Turkish Cotton Industry, the Australian Cotton Industry, the Committee for International Cooperation among Cotton Associations (CICCA), and the International Textiles Manufacturers Federation (ITMF). ${ }^{72}$

The ICA further initiated a training program to globalize its network of arbitrators. While this meant decentralizing control over arbitration processes, an ICA representative explained its rationale:

The ICA is encouraging more overseas arbitrators. Right now, more than half of arbitrators are UK-based. But we need arbitrators in China, in India. We've got to do it, there is no choice really. We need the credibility. . . If we can certify 
arbitrators across the world, then people aren't so against it just being some decision coming down from Liverpool. But they can say, I've got my own guy here, my ICA arbitrator in my own country who speaks my language. And then my arbitration panel might have someone from Brazil on it and an independent person appointed by the ICA—so you'd really feel like you were getting an unbiased opinion.

In October 2006 at their annual meetings, the ICA held the first-ever examination to become a certified ICA arbitrator. In the first seven months, thirty-one members, from the United Kingdom, the United States, Switzerland, Germany, China, Singapore, and Belgium, passed the Level 1 Arbitrator Training Course exam; twenty more were scheduled to take the exam by the end of $2007 .^{73}$

In perhaps its most significant concession to establish greater representation, the ICA decided to strategically diversify its Rules Committee. At its annual meeting in 2006, it announced that every trade association that adopted the ICA rules would be given a seat on the ICA Rules Committee. The Rules Committee debated rule changes and drafted proposals to be approved by the membership. A representative of the ICA explained the rationale behind this decision:

We will tell every cotton association, if they accept our rules, they can have a spot on our rules committee. So then they feel like they have a say in it, it is not just Liverpool telling them what to do.

By offering to incorporate other trade associations into the Rules Committee, the ICA was loosening control over this key agenda-setting function in order to gain broader support for its leadership in the sector. In sum, by changing rules, by framing them as representing business ethics, and by incorporating a broader spectrum of actors within its institutional structure, the ICA hoped to legitimate its claims to be an impartial and globally representative association.

Trade associations representing textile manufacturers and merchants in different regions responded differently to the ICA's bid for hegemony based on their shifting competitive positions. As the ICA had pursued its hegemonic project, the ECC had successfully standardized the rules of the European trade associations. The Gydnia Cotton Association in Poland, the Belgian Cotton Association, the Association Française Cotonière (AFCOT) in France, and the Centro Algodonero Nacional in Spain had officially adopted the ECC rules. However, as the European textile sector had continued to decline (see Figure 5), ECC standardization efforts fractured. Given that many ECC industries could soon cease to exist, the Bremen Cotton Exchange in Germany instead chose to adopt the ICA rules. ${ }^{74}$ The ICA president held up the Bremen Cotton Exchange as an example:

[T]onight I call upon all other associations to support us in this [standardization] task through closer cooperation. Bremen is a fine example of this cooperation: 
they support the idea of "one set of rules" and are currently working on replacing the Bremen Rules with the International Rules. This is a vital step towards harmonization. We appeal to the remaining associations to join this process. In Abraham Lincoln's words: united we stand, divided we fall. ${ }^{75}$

Soon after, an ICA representative reported that the Belgian Cotton Association, the Gdynia Cotton Association, and the Centro Algodonero Nacional had initiated discussions regarding the adoption of ICA rules. The Gdynia Cotton Association officially adopted the ICA rules in 2010. From a depressed market position, these European associations began to see seats on the ICA's Rule Committee as their best bet to maintain decision-making power over contract rules as their economic power dwindled.

However, the French association, AFCOT, was reluctant to adopt ICA rules, given their distinct position within the global cotton trade. The French textile industry had declined, but French cotton merchants were attempting to compete in the increasingly consolidated merchant sector. The French merchant Geocoton, in particular, had taken over the former French SOE CFDT, which had enjoyed export monopolies in West African countries in the postcolonial period. ${ }^{76}$ As its formal export monopolies ended with the privatization of both French and West African SOEs, Geocoton wanted to maintain its regional advantage in West Africa and saw use of its own contract rules as one way to do so. ${ }^{77}$ AFCOT reported that it aimed to maintain its special link to West African countries, including a French-speaking cotton culture, through the elaboration of common rules for contract sanctity and arbitration. ${ }^{78}$ By maintaining the French AFCOT rules, the merchants in AFCOT hoped to solidify relationships with the new class of West African domestic merchants emerging in the wake of SOE privatization.

While AFCOT was reluctant to adopt ICA rules, the leadership of the African Cotton Association (ACA) at the time took a role in promoting their adoption. From the perspective of some West African domestic merchants, adopting the ICA rules could be strategic. As the French now had to compete with other merchants to source African cotton, African merchants and producers hoped to play several companies against each other to escape to some degree the price-fixing that came with the French export monopoly. Becoming fluent in the ICA rules could help African merchants better exercise their new bargaining power. Leaders of the ACA thus began to work with the ICA to facilitate workshops in African countries on how to use ICA rules.

Finally, the Indian trade associations, ${ }^{79}$ which had expressed resistance to the ICA rules in the past, had begun internal discussions around their adoption. Since the ICA launched its initial efforts to lead the standardization of contract rules, the Indian textile sector had grown significantly, becoming the second largest consumer of raw cotton in the world behind China. ${ }^{80}$ Much like the CCA, there were benefits to adoption for Indian textile manufacturers: improving their reputation for contract sanctity to access on-call pricing. As such, representatives of the Indian industry decided to at least consider the ICA rules, as a representative of the Cotton Association of India (CAI) commented: "We want to study them. We've formed a committee . . over the next year we are going to compare [the ICA rules] to our rules and see what we would 


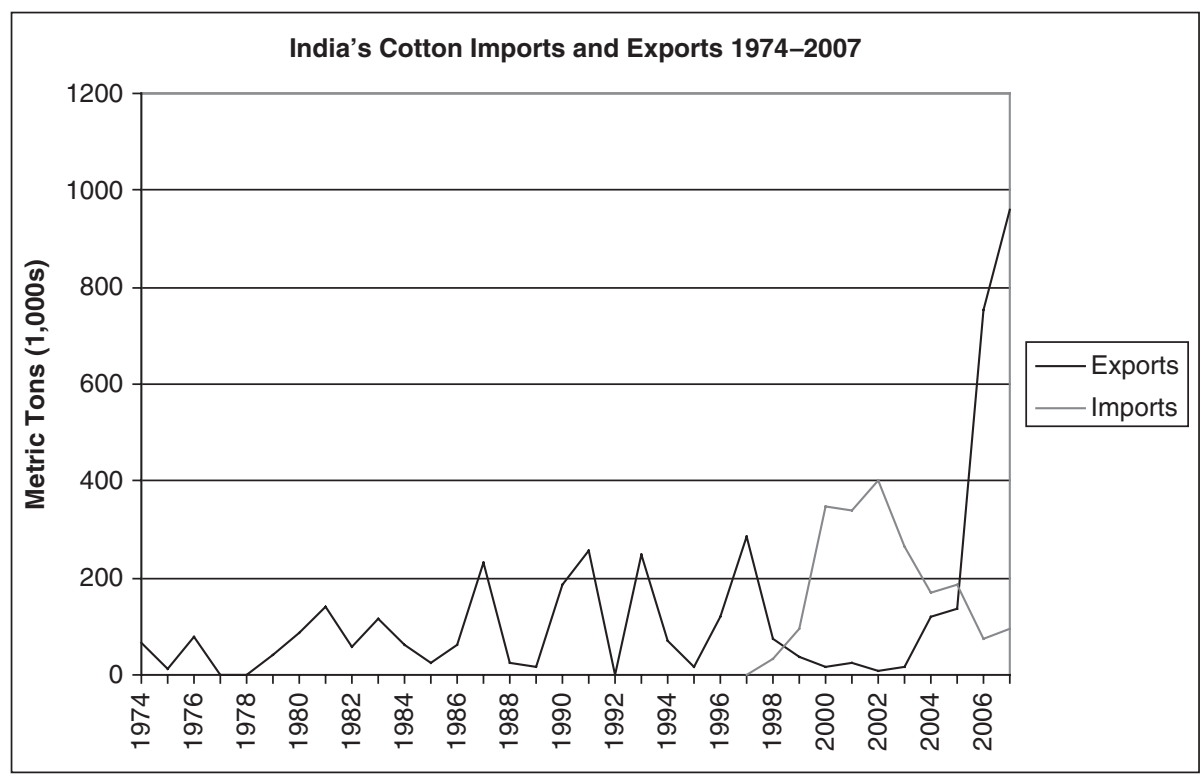

Figure 7.

lbid.

be agreeing to, if we were to adopt them." But actors in the Indian sector still had misgivings regarding what they saw as a largely top-down imposition of the ICA rules. For example, as a panel of ICA representatives gave updates on the standardization process at the 2006 ICAC meetings, an Indian merchant reminded participants that what was needed was not just updates but a "consultative and consensus process."

Despite this plan to consider the ICA rules, another opportunity was emerging for Indian merchants. In the course of a few years, India's cotton production had dramatically increased due to rising yields. ${ }^{81}$ The Indian sector surpassed the United States to become the second-largest cotton producer in the world behind China. As production significantly outstripped consumption, India radically increased its exports (see Figure 7), and its share of world cotton exports increased from 8 percent to 12 percent from 2005 to $2007 .^{82}$ Moreover, Indian merchants enjoyed a competitive advantage as the cotton trade became focused on China. Indian cotton was selling for three to five cents lower per pound than U.S. cotton given lower transport costs. ${ }^{83}$ With its increasingly significant position on the export market, resistance to the ICA rules made sense as part of Indian merchants' broader expansionary strategy. As an Indian merchant commented, "we were working on moving to the ICA rules ... but [now] there is not as much interest in moving it forward." With growing exports, Indian merchants had the potential to "hook on" to China's rapid growth by establishing direct trading relationships with Chinese textile manufacturers, allowing them to bypass transnational merchants and the ICA rules. 
In sum, the ICA had made inroads in its attempts to construct it leadership and control over cotton contract rules. Some trade associations had indeed begun adoption of the ICA rules. However, the ICA's hegemonic project, launched due to the challenge posed by the CCA, created new strategic opportunities for weaker actors to demand greater representation in contract governance and, in the case of AFCOT and the CAI, to try to undermine the ICA's claim to sectoral leadership. In terms of its broader goal to increase bargaining leverage vis-à-vis China, the ICA's success was mixed. In a demonstration of its growing willingness to negotiate with the global cotton community, the CCA joined CICCA in 2007-an important step given CICCA's close cooperation with the ICA and China's general refusal as yet to participate in other international cotton bodies. Transnational merchants also convinced the CCA to work with them to offer educational workshops on rules for contracts and dispute arbitration for Chinese spinners. Despite these signs of cooperation, the CCA remained dedicated to the promotion of the CCA contract and CIETAC arbitration. As of 2009, while some standardization has been achieved, contestation continues over whose rules will govern cotton contracts on a global stage.

\section{Conclusion}

Evidence from the case suggests that we need a more dynamic model of institution building in order to understand emerging forms of coordination and governance structures within commodity chains. Western, transnational merchants are not unrivalled in their attempt to claim institutional power in the cotton trade, as GCC scholarship often implies through its emphasis on ideal types of corporate-led governance structures. Rather, the Chinese state made its own bid to set rules to govern cotton imports to ensure the competitiveness of its textile and apparel sectors. This indicates the need to revise existing accounts in order to explore contested processes of institutionbuilding in commodity chains. Such an approach allows us to explore not only how a commodity chain is governed but also how a given governance structure and the forms of coordination that underpin it emerge and are constructed as legitimate.

Understanding how private governance is constructed as legitimate and thus enforceable requires a revision and extension of GCC/GVC scholarship. First, we need to complicate the conceptualization of agency within GCC/GVC analyses. While the GCC framework does see transnational firms as agents that organize commodity chains to serve their interests, by failing to consider the legitimacy of these arrangements, agency becomes narrowly defined in terms of who can exercise the most economic power. The GVC framework tends to overlook agency entirely.

The case of cotton contract rules lays bare the overly static view of governance that results from these approaches and demonstrates the need to consider how strategic action and competition shape institution-building. Who would control contract rules could not be read off the economic structure. Rather, actors strategized and struggled to construct a set of rules and an institutional structure that would best reflect their interests and be accepted by other actors. These were not unrivalled "lead" actors but 
institutional entrepreneurs actively reconfiguring institutional arrangements to solve their problems. In this view, it was strategic action that played a critical role in constructing the - albeit partial and tentative-legitimacy of the ICA rules.

Yet, this strategic action in negotiations was constrained by the broader institutional context in which negotiations were embedded. This points to another revision required in the existing framework. GCC/GVC scholars have been widely criticized for focusing on variables endogenous to commodity chains to explain governance, ignoring the broader institutional context in which commodity chains are embedded. However, broader institutional shifts play a critical role in constituting the overall power dynamics in a commodity chain. It was shifts in the broader institutional context - the end of the MFA and the accession of China to the WTO - that reconfigured power dynamics, making China a major player in contract rule negotiations.

Broader institutional arrangements structured both the material and discursive terrain of struggle in the cotton trade. In transnational merchants' efforts to persuade others to accept their rules and trade association, they enjoyed a privileged position. Their preferred institutional arrangements for private contract governance had already been globalized in the 1958 New York Convention, and many states had been compelled to sign on to this Convention through structural adjustment programs. Moreover, this Convention had legitimized discourses about what made contract governance fair, specifically the idea that actors enter into contracts freely and consensually. Transnational merchants were able to draw on and reconstruct these discourses in their effort to define ethical business practices and legitimate their rules.

The case of cotton contract rules also complicates our understanding of institutional context in another way. Exploring institutional context means considering not only new supranational institutions, discourses, and agreements but also the diverse institutional arrangements in which different actors have historically been embedded. As economic geographers and varieties of capitalism scholars have suggested, we need to account for institutional variation across space.

GCC/GVC research has largely ignored such variation. From this view, actors' interests and strategies can be understood by virtue of their functional position on the commodity chain. As negotiations in the cotton trade suggest, this perspective overlooks other critical dimensions. In the cotton trade, different actors have historically been embedded in different institutional arrangements for governing contracts, such as private versus state governance, governance of nationally versus regionally versus postcolonial-focused trade, and governance embedded in different state legal systems. As such, actors have developed distinct business practices, customs, and competencies, as well as understandings of what makes contract governance fair. Actors' distinct institutional embeddedness critically shaped how they responded to transnational merchants' bid to control contract rules. This is not to say that an actor's functional position in a chain does not matter. Indeed, a key point of contention between transnational merchants and the Chinese state was over their different interests in how quality would be governed, given their positions as sellers vs. buyers. However, functional position alone is not sufficient for understanding why the issue of whose arbitral body 
would settle disputes was a critical point of contention. It is only by considering institutional variation across space that we can trace the advantages gained by compelling others to "play by your rules."

A broader view of strategic action, competitive dynamics, and institutional context also raises new questions for Gereffi's typology of chains and the general claim that chains are becoming more buyer-driven in the current era. My case tentatively confirms that the trader-driven nature of the cotton chain is being challenged by buyerdriven dynamics. However, Gereffi's typology leaves us unable to account for how and why such changes emerge except to posit the growing power of retailers. Evidence from this case and existing scholarship suggests that a more complex analysis is necessary. Gibbon and Ponte argue that changes in trade rules can influence whether producers or buyers "drive" a particular commodity chain. ${ }^{84}$ I confirm this claim, as we see how the end of the MFA and the accession of China to the WTO upset the initial trader-driven nature of the chain. However, my analysis further suggests that the trader- versus buyer-driven nature of the cotton trade is a point of contestation, and the victor will not emerge through economic dominance alone. Rather, who drives a chain should be understood as constructed through competition for both economic and institutional power.

In sum, evidence from the cotton trade demonstrates the need for modifications to the GCC/GVC framework. I have put forth a more dynamic model that captures how private governance is constructed through the intersection of strategic action, dominant discourses, existing institutional arrangements, and competitive dynamics. These findings underline the importance of attending to institutional context, institutional variation across space, and the cultural political economy of commodity chains. It is only by exploring this more dynamic process of institution-building that we can understand how and why transnational governance arrangements emerge and are established as legitimate and enforceable.

\section{Acknowledgments}

I would like to thank Jane Collins, Brent Kaup, Gay Seidman, Erik O. Wright, Jonathan Zeitlin, Patrick Heller, and the editorial board of Politics \& Society for useful feedback on earlier drafts of this manuscript.

\section{Declaration of Conflicting Interest}

The author declared no conflicts of interest with respect to the authorship and/or publication of this article.

\section{Funding}

This research was generously funded by fellowships from the Social Sciences and Humanities Research Council of Canada (SSHRC), the Dr. Margaret McWilliams Pre-Doctoral Fellowship of the Canadian Federation of University Women, and the Wisconsin Distinguished Graduate Fellowship from the University of Wisconsin-Madison. 


\section{Notes}

1. Edward Wong, Jonathan Ansfield, and Sharon LaFraniere, "China Paints Google Issue as Not Political," New York Times, January 20, 2010.

2. Jennifer Bair, "Global Capitalism and Commodity Chains: Looking Back, Going Forward," Competition and Change 9, no. 2 (2005): 153-80.

3. Martin Hess, "'Spatial' Relationships? Towards a Reconceptualization of Embeddedness," Progress in Human Geography 28, no. 2 (2004): 165-86.; Martin Hess and Henry Wai-chung Yeung, "Whither Production Networks in Economic Geography?" Environment and Planning A 38 (2006): 1205-27.

4. Peter Gibbon and Stefano Ponte, Trading Down: Africa, Value Chains, and the Global Economy (Philadelphia: Temple, 2005).

5. Hess and Yeung, "Whither Production Networks in Economic Geography?"

6. Terrence K. Hopkins and Immanuel Wallerstein, "Patterns of Development of the Modern World-System," Review 1, no. 2 (1977): 11-145.

7. Gary Gereffi, "The Organization of Buyer-Driven Global Commodity Chains: How U.S. Retailers Shape Overseas Production Networks," in Commodity Chains and Global Capitalism, ed. Gary Gereffi and Miguel Korzeniewicz (Westport, CT: Praeger, 1994), 95-122.

8. John Humphrey and Hubert Schmitz, "How Does Insertion in Global Value Chains Affect Upgrading in Industrial Clusters?” Regional Studies 36, no. 9 (2002): 1017-27.

9. Jennifer Bair, "Global Commodity Chains: Genealogy and Review," in Frontiers of Commodity Chain Research, ed. Jennifer Bair (Stanford, CA: Stanford University Press, 2009), $1-34$.

10. Gary Gereffi, John Humphrey, and Timothy Sturgeon, "The Governance of Global Value Chains," Review of International Political Economy 12, no. 1 (2005): 78-104; Timothy Sturgeon, "Modular Production Networks. A New American Model of Industrial Organization," Industrial and Corporate Change 11, no. 3 (2002): 451-96; Timothy Sturgeon, "From Commodity Chains to Value Chains: Interdisciplinary Theory Building in an Age of Globalization," in Frontiers of Commodity Chain Research, ed. Jennifer Bair (Stanford, CA: Stanford University Press, 2009), 110-35.

11. Gereffi et al. ("The Governance of Global Value Chains") refer to these as governance structures, which suggests that this new typology is meant to replace Gereffi's ("The Organization of Buyer-Driven Global Commodity Chains") earlier producer-versus buyerdriven distinction. Here I follow Gibbon and Ponte (Trading Down) who suggest that Gereffi et al. are actually referring to "forms of coordination" such as standards and contracts that are embedded within broader governance structures (see also Sturgeon, "From Commodity Chains to Value Chains").

12. Benjamin Cashore, Graeme Auld, and Deanna Newsom, Governing through Markets: Forest Certification and the Emergence of Non-State Authority (New Haven, CT: Yale University Press, 2004), 220.

13. Ibid., 220, original emphasis. 
14. John Bowman, Capitalist Collective Action (New York: Cambridge University Press, 1989); Harland Prechel, "Steel and the State: Industry Politics and Business Policy Formation, 1940-1989," American Sociological Review 55, no. 5 (1990): 648-68; see also Cashore et al., Governing through Markets.

15. Giovanni Arrighi and Beverly Silver, "Capitalism and World (Dis)Order," Review of International Studies 27 (2001): 257-79.

16. Gary G. Hamilton and Gary Gereffi, "Global Commodity Chains, Market Makers, and the Rise of Demand-Responsive Economies," in Frontiers of Commodity Chain Research, ed. Jennifer Bair (Stanford, CA: Stanford University Press, 2009), 136-62.

17. Richard P. Appelbaum, "Big Suppliers in Greater China: A Growing Counterweight to the Power of Giant Retailers," in China and the Transformation of Global Capitalism, ed. Ho-fung Hung, (Baltimore, MD: The Johns Hopkins University Press, 2009), 66.

18. Ho-fung Hung, "Introduction: The Three Transformations of Global Capitalism," in China and the Transformation of Global Capitalism, ed. Ho-fung Hung (Baltimore, MD: The Johns Hopkins University Press, 2009), 17.

19. Bair, "Global Commodity Chains"; Peter Gibbon, Jennifer Bair, and Stefano Ponte, “Governing Global Value Chains: An Introduction," Economy and Society 37, no.3 (2008): 315-38; Philip Raikes, Michael Friis Jenson, and Stefano Ponte, "Global Commodity Chain Analysis and the French Filière Approach: Comparison and Critique," Economy and Society 29, no. 3 (2000): 390-417.

20. Bair, "Global Commodity Chains"; Hess and Yeung, "Whither Production Networks in Economic Geography?"

21. Gereffi et al., "The Governance of Global Value Chains," 99, emphasis added.

22. Laszlo Czaban and Jeffrey Henderson, "Globalization, Institutional Legacies and Industrial Transformation in Eastern Europe," Economy and Society 27, no. 4 (1998): 585-613; Peter Dicken and Anders Malmberg, "Firms in Territories: A Relational Perspective," Economic Geography 77, no. 4 (2001): 345-63; Gibbon and Ponte, Trading Down.

23. J. Rogers Hollingsworth and Robert Boyer. Contemporary Capitalism: The Embeddedness of Institutions (Cambridge: Cambridge University Press, 1997); Peter Hall and David Soskice, eds., Varieties of Capitalism (Oxford: Oxford University Press, 2001); Richard D. Whitley, "Business Systems and Global Commodity Chains: Competing or Complementary Forms of Economic Organization?" Competition and Change 1, no. 4 (1996): 411-25; Richard D. Whitley, Divergent Capitalisms: The Social Structuring and Change of Business Systems (New York: Oxford University Press, 1999).

24. Hess, “'Spatial' Relationships?”

25. Gary Gereffi, "International Trade and Industrial Upgrading in the Apparel Commodity Chain," Journal of International Economics 48, no. 1 (1999): 37-70.

26. Gibbon et al., "The Governance of Global Value Chains."

27. Fred Block, "Rethinking Capitalism," in Readings in Economic Sociology, ed. N. W. Biggard (Oxford, UK: Blackwell, 2002), 224.

28. Paul DiMaggio, "Interest and Agency in Institutional Theory," in Institutional Patterns and Organizations: Culture and Environment, ed. L. G. Zucker (Cambridge, MA: Ballinger, 1988), 3-22; Paul DiMaggio and Walter Powell, "Introduction," in The New Institutionalism in 
Organizational Theory, ed. W. Powell and P. DiMaggio (Chicago: University of Chicago Press, 1991), 3-45.

29. See also Bob Jessop, State Theory: Putting the Capitalist State in Its Place (Cambridge, UK: Polity, 1990).

30. Marie-Laure Djelic and Sigrid Quack, "Theoretical Building Blocks for a Research Agenda Linking Globalization and Institutions," in Globalization and Institutions: Redefining the Rules of the Economic Game, ed. M. Djelic and S. Quack (Cheltenham, UK: Edward Elgar, 2003), 18.

31. Boaventura de Sousa Santos, Toward a New Common Sense: Law, Science and Politics in the Paradigmatic Transition (London: Routledge, 1995).

32. Neil Fligstein, "Markets as Politics: A Political-Cultural Approach to Market Institutions," American Sociological Review 61, no. 4 (1996): 659.

33. Dirk Lehmkuhl, "Structuring Dispute Resolution in Transnational Trade: Competition and Coevolution of Public and Private Institutions," in Globalization and Institutions: Redefining the Rules of the Economic Game, ed. M. Djelic and S. Quack (Cheltenham, UK: Edward Elgar, 2003), 278-301. See also, A. Claire Cutler, Private Power and Global Authority: Transnational Merchant Law in the Global Political Economy (Cambridge: Cambridge University Press, 2003); Yves Dezalay and Bryant Garth, "Merchants of Law as Moral Entrepreneurs: Constructing International Justice from the Competition for Transnational Business Disputes," Law \& Society Review 29, no. 1 (1995): 27-64; Yves Dezalay and Bryant G. Garth, Dealing in Virtue: International Commercial Arbitration and the Construction of a Transnational Legal Order (Chicago: University of Chicago Press, 1996); Walter Mattli, "Private Justice in a Global Economy: From Litigation to Arbitration," International Organization 55, no. 4 (2001): 919-47.

34. Peter Gibbon, "Upgrading Primary Production: A Global Commodity Chain Approach," World Development 29, no. 2 (2001): 345-63. In later work, Gibbon and Ponte (Trading Down) argue that the cotton trade is not driven by any set of lead actors. I believe that they are mistaken in this assessment. This is perhaps because they rely heavily on secondary sources for data on the cotton trade. Many secondary sources suggest that the merchant node is highly competitive. However, interview data, as well as analysis of news reports of mergers and acquisitions among merchant firms, suggests that the degree of consolidation among merchants is considerably underestimated in most accounts. Here see Koray Caliskan, "Making a Global Commodity: The Production of Markets and Cotton in Egypt, Turkey and the United States," PhD diss., Department of Politics, New York University.

35. John M. Talbot, Grounds for Agreement: The Political Economy of the Coffee Commodity Chain (Rowman \& Littlefield: New York, 2004).

36. Talbot, Grounds for Agreement; John M. Talbot, "The Comparative Advantages of Tropical Commodity Chain Analysis," in Frontiers of Commodity Chain Research, ed. Jennifer Bair (Stanford, CA: Stanford University Press, 2009), 93-109.

37. Talbot, Grounds for Agreement.

38. CFA refers to la Communauté financière d'Afrique, or the Financial Community of Africa. The CFA zone includes Benin, Burkina Faso, Cameroon, Central African Republic, Chad, Cote d'Ivoire, Mali, Niger, Senegal, Togo, and Guinea-Bissau. 
39. International Cotton Advisory Committee, Documents of the ICAC (CD-ROM), vol. 15 (Washington, DC: International Cotton Advisory Committee, 2008).

40. Ibid.

41. Caliskan, "Making a Global Commodity."

42. Pakistan privatized cotton marketing in the late 1980s; India followed suit in the early 1990s. In East Africa, Tanzania, Uganda, and Zimbabwe began liberalizing market and trade regimes for cotton in the early 1990s. In West Africa, Bénin and Cote d'Ivoire introduced some liberalization measures in the late 1990s and early 2000s. Other West African countries, such as Mali, Chad, and Burkina Faso, were supposed to privatize their SOEs as part of structural adjustment programs in the late 1990s and early 2000s, but they have not done so, or have only partially carried out reforms. SOEs continue to play an important role in cotton marketing in other countries as well, such as Uzbekistan and China, as Chinatex has only been partially privatized. See John Baffes, "Policy Reform Experience in Cotton Markets," in Commodity Market Reforms: Lessons of Two Decades, ed. Takamasa Akiyama, John Baffes, Donald Larsen, and Panos Varangis (Washington, DC: The International Bank for Reconstruction and Development/The World Bank, 2001), 165-90; John Baffes, "The 'Cotton Problem' in West and Central Africa: The Case for Domestic Reforms," Cato Institute Economic Development Bulletin 11 (July 10, 2007), http://www.cato.org/pub_display .php?pub_id=9302 (accessed April 1, 2009).

43. Private authority over contract rules was not new to this period. Private actors constructed authority to set contract rules, settle disputes through private arbitration, and enforce arbitral decisions as early as the medieval period. See Cutler, Private Power and Global Authority.

44. B. M. Cremades and S. L. Plehn, "The New Lex Mercatoria and the Harmonization of the Laws of International Commercial Transactions," Boston University International Law Journal 2 (1983): 317-48; J. P. Robé, "Multinational Enterprises: The Constitution of a Pluralistic Legal Order," in Global Law without a State, ed. G. Teubner (Brookfield, VT: Dartmouth, 1997), 45-77.

45. Cremades and Plehn, "The New Lex Mercatoria and the Harmonization of the Laws of International Commercial Transactions"; Cutler, Private Power and Global Authority.

46. Cutler, Private Power and Global Authority, 157.

47. Ibid.

48. John Braithwaite and Peter Drahos, Global Business Regulation (Cambridge: Cambridge University Press, 2000).

49. George S. Busch, An American Harvest: The Story of Weil Brothers-Cotton (Englewood Cliffs, NJ: Prentice-Hall, 1982).

50. Industry players suggest that the CCA, like other "private" business associations in China, is actually better characterized as a "quasi-public" association with limited autonomy from the state. While technically private, in practice, the state continued to exercise significant control over the CCA and thus over the negotiation of contract rules. See Jonathan Unger, “"Bridges': Private Business, the Chinese Government and the Rise of New Associations," The China Quarterly 147 (1996): 795-819.

51. Dezalay and Garth, "Merchants of Law as Moral Entrepreneurs." 
52. Ibid., 52; see also S. L. Sempasa, "Obstacles to International Commercial Arbitration in African Countries," The International and Comparative Law Quarterly 41, no. 2 (1992): $387-413$.

53. Santos, Toward a New Legal Common Sense.

54. China Cotton Association, "Cotton Purchase Contract: Applicable to Non-Chinese Made Cotton Trade" (2006).

55. Liverpool Cotton Association Limited, Annual Report and Accounts 2003 (Liverpool, UK: The Liverpool Cotton Association, 2003), http://www.ica-ltd.org (accessed June 18, 2007).

56. International Cotton Association Limited, Annual Report and Accounts 2005 (Liverpool, UK: The International Cotton Association, 2005), http://www.ica-ltd.org (accessed June 18, 2007).

57. International Cotton Association Limited, Annual Report and Accounts 2005; International Cotton Association Limited, Annual Report and Accounts 2006 (Liverpool, UK: The International Cotton Association, 2006), http://www.ica-ltd.org (accessed June 18, 2007).

58. International Cotton Association Limited, Bylaws and Rules of the International Cotton Association Limited (Liverpool, UK: The International Cotton Association, 2009), rule 226, http://www.ica-ltd.org (accessed April 1, 2009); see by contrast European Cotton Confederation, European Cotton Rules, http://www.afcot.org (accessed April 13, 2009).

59. International Cotton Association Limited, Bylaws and Rules of the International Cotton Association Limited.

60. The continental European cotton associations are: the Association Française Cotonnière (AFCOT, France), the Belgium Cotton Association (Belgium), the Bremen Cotton Exchange (Germany), the Centro Algodonero Nacional (Spain), the Gdynia Cotton Association (Poland), and the Associazione Tessile Italiana (Italy).

61. Zbigniew Roskwitalski, "Standardization of Trade Rules," paper presented at the 65th Plenary Meeting of the International Cotton Advisory Committee, Goiania, Brazil (11-15 September 2006), http://www.icac.org (accessed June 18, 2007).

62. Rajaram Jaipuria, "Improvement of Cotton Trading Practices: Prospects and Problems," Express Textile, January 13, 2005.

63. G. Gurumurthy, "LCA Arbitration Rules Bug Cotton Importers," Business Line, June 3, 2001.

64. Liverpool Cotton Association Limited, Annual Report and Accounts 2003.

65. International Cotton Association Limited, Annual Report and Accounts 2004 (Liverpool, UK: The International Cotton Association, 2004), http://www.ica-ltd.org (accessed June $18,2007)$.

66. Ibid.

67. Liverpool Cotton Association Limited, Annual Report and Accounts 2003.

68. This reflected broader neoliberal discourses about trade that differentiate between the impartiality of a "universal free trade model" and the "unfairness" of alternative trade practices, such as protectionism.

69. International Cotton Association Limited, Annual Report and Accounts 2005; International Cotton Association Limited, Annual Report and Accounts 2006. 
70. International Cotton Association Limited, Annual Report and Accounts 2006; International Cotton Association Limited, ICA Members Newsletter 16 (2007), http://www.ica-ltd.org (accessed June 18, 2007); International Cotton Association Limited, Membership Directory 2009, Incorporating Annual Review 2008 (Liverpool, UK: International Cotton Association Limited, 2009), http://www.ica-ltd.org (accessed December 15, 2009).

71. International Cotton Association Limited, "The International Cotton Association Limited," http://www.ica-ltd.org (accessed June 18, 2007).

72. Ibid.

73. International Cotton Association Limited, ICA Members Newsletter.

74. Jan B. Wellmann, "Standardised Trading Rules: Incorporating ICA Rules in the Rules of the Bremen Cotton Exchange," paper presented at the 64th Plenary Meeting of the International Cotton Advisory Committee, Liverpool, England (September 27, 2005), http://www .icac.org (accessed June 18, 2007).

75. International Cotton Association Limited, Annual Report and Accounts 2005.

76. Geocoton was previously the state-owned CFDT, la Compagnie Française pour le Développement des Textiles, or the French Textile Development Company. After former French colonies in West Africa received their independence, the CFDT secured export monopolies through joint ventures with these new governments and their cotton SOEs. The West African SOEs thus bargained on behalf of cotton producers, but they were compelled to sell most if not all of their cotton to CFDT. The CFDT was partially privatized in 2001 and became known as Développement des Agro-Industries du Sud, or DAGRIS. In 2008, Geocoton gained majority share and the firm took this name. See Thomas J. Bassett, Thomas J., The Peasant Cotton Revolution in West Africa: Cote d'Ivoire 1880-1995 (Cambridge: Cambridge University Press, 2001); James R. Bingen, "Cotton, Democracy, and Development in Mali," The Journal of Modern African Studies 36, no. 2 (1998): 265-85.

77. The privatization of the West African SOEs under structural adjustment programs meant the loss of CFDT/Geocoton's export monopolies in these countries. Without its export monopolies, CFDT/Geocoton had to compete with an increasingly consolidated group of transnational merchants that wanted to access this newly open market.

78. Cotton International, "AFCOT Expanding Reach in Europe, Africa," Cotton International: World Report 3, no. 9 (September 2005): 24.

79. There are a number of trade associations operating in the cotton sector in India, which participate in transnational forums such as the ICA to differing degrees. The Cotton Association of India, previously the East Indian Cotton Association, is attempting to position itself as representative of the national industry, but appears to be dominated by more transnationally focused actors and particularly merchants who handle large enough volumes to warrant membership in the ICA and are capable of participation in transnational forums.

80. International Cotton Advisory Committee, Documents of the ICAC (CD-ROM).

81. In India, yields have increased from $302 \mathrm{~kg}$ per hectare in $2002 / 2003$ to $520 \mathrm{~kg}$ per hectare in 2006/2007-a 72 percent increase over four seasons. See Armelle Gruere, "2007/08 World Cotton Outlook," paper presented to the 9th International Cotton Conference, Gdansk, Poland, 6-7 September 2007, http://www.icac.org (accessed April 4, 2008).

82. Gruere, "2007/08 World Cotton Outlook." 
83. Tommy Horton, "Understanding China: U.S. Industry Group Believes Trip Accomplished Goals," Cotton Farming (August 2008): 12-14.

84. Gibbon and Ponte, Trading Down.

\section{Bio}

Amy A. Quark (aaquark@wm.edu) is an assistant professor of sociology at the College of William \& Mary. Her research focuses on the intersection of transnational corporate power and intensified geopolitical competition in the construction of global economic governance. She is currently working on a book manuscript that examines how China, the United States, and transnational merchants compete to construct legitimate authority to govern quality standards and contract rules in the global cotton trade. 